\title{
STRATEGI KARYAWAN DALAM MENINGKATKAN MINAT NASABAH MENABUNG DI BMT MASLAHAH CAPEM TEGAL SIWALAN
}

\author{
Abd Ghafur \\ Email: ghafuroke@gmail.com \\ Universitas Zainul Hasan Genggong \\ Iis Nurus Shobah \\ Universitas Zainul Hasan Genggong
}

\begin{abstract}
Baitul Maal wa Tamwil (BMT) Maslahah Capem Tegalsiwalan which is a financial institution that implements a system based on Islamic sharia. In its application it does not use the principle of interest (Riba) but instead uses the principle of profit sharing (Nisbah) so as to guarantee the halal income. The goal of every company is to create satisfied customers. So we need the right service strategy to be able to provide satisfaction to customers and maintain customers. The purpose is to find out service to customer satisfaction, it can be known the cause of customer interest to save, namely the quality of BMT services Maslahah Capem Tegalsiwalan that satisfies customers, and it is known that the Sumberbulu community positively welcomed the presence of BMT Maslahah Capem Tegalsiwalan because the services provided by BMT employees Maslahah Capem Tegalsiwalan Tegalsiwalan is very good, public appreciation is more caused by the performance of BMT employees Maslahah Capem Tegalsiwalan who are all alumni of Islamic Boarding Schools, they show a positive attitude in serving customers. In addition, savings products provided by BMT Maslahah Capem Tegalsiwalan can be taken at any time if there is an urgent need, and there is a profit sharing every month. The procedure is quite easy, it is also the reason for customers to choose to save at BMT Maslahah Capem Tegalsiwalan.
\end{abstract}

Keywords: Employee Efforts. Savings Customer Interest 


\section{PENDAHULUAN}

Indonesia yang mayoritas penduduknya beragama islam menyebabkan banyak terjadinya muamalah dalam memenuhi kegiatan ekonomi secara islami, kegiatan tersebut akan melibatkan lembaga keuangan islam. Saat ini, banyak sekali penghasilan masyarakat yang tidak berimbang dengan angka kebutuhan kehidupannya. Dengan kata lain, masih belum tercukupi penghasilan yang diperoleh masyarakat dengan kebutuhan hidupnya. Maka dari itu, lembaga keuangan syariah memberikan solusi untuk mengatasi angka kemiskinan.

Ditengah problematika diatas, Lembaga keuangan Syariah lahir sebagai salah satu solusi alternatif yang dapat di tempuh terhadap persoalan pertentangan antara bunga bank dengan riba. Dengan demikian, pada tahun 1990an telah terpenuhi untuk melepaskan diri dari persoalan riba dengan lahirnya Keuangan Syariah di Indonesia. Bank Syariah adalah bank yang melakukan operasionalnya sesuai dengan prinsip-prinsip syariah Islam atau tata cara beroperasinya mengacu pada ketentuan Al-Qur'an dan Hadits. ${ }^{1}$ Bank Syariah memiliki karakter yang berbeda dengan bank konvensional, yaitu menghilangkan bunga sebagai instrumen utama dan menggantikannya dengan prinsip bagi hasil yang lebih sesuai dengan prinsip perekonomian dalam Islam.

Di awali berdirinya Bank Muamalat Indonesi (BMI) pada tahun 1992 timbul peluang untuk mendirikan lembaga-lembaga keuangan berprinsip syariah, karena BMI kurang menjangkau usaha kecil dan menengah sehingga munculah usaha untuk mendirikan lembaga keuangan mikro seperti BMT (Baitul Maal wat tamwil). Hal ini memunculkan kesempatan untuk mendirikan lembaga-lembaga keuangan dengan prinsip Syariah seperti, Bank Syariah, Koperasi Syariah, Asuransi Syariah, Baitul Maal Wat Tamwil (BMT), Pegadaian Syariah dan lain sebagainya. ${ }^{2}$

BMT (Baitul Maal wat tamwil) berasal dari dua kata yaitu baitul mal dan baitul tamwil. baitul tamwil berarti rumah penyimpanan harta milik pribadi yang dikelola oleh suatu lembaga. ${ }^{3}$ BMT (Baitul Maal wat tamwil) menghimpun dana masyarakat dalam bentuk tabungan, yang terdiri dari tabungan mudharabah dan tabungan wadiah. BMT Maslahah Capem Tegalsiwalan memberikan pelayanan tabungan mudharabah dan tabungan wadiah, tetapi di dalam BMT Maslahah Capem Tegalsiwalan mayoritas

\footnotetext{
${ }^{1}$ Ahmad Ifham Sholihin, Buku Pintar Ekonomi Syariah (Jakarta: PT Gramedia Pustaka Utama Kompas Gramedia Building, 2010), 150.

${ }^{2}$ Muhammad Syafi'i Antonio, Bank Syariah dari Teori ke Praktek (Jakarta : Gema Insani, 2001), 25.

${ }^{3}$ Suhrawardi K. Lubis, Hukum Ekonomi Islam (Jakarta: Sinar Grafika, 2000), 114.
} 
nasabah menggunakan tabungan mudharabah karena tabungan ini bisa di ambil sewaktu-waktu dengan kesepakatan kedua belah pihak.

BMT Maslahah Capem Tegalsiwalan menerapkan "sistem jemput bola" dengan mendatangi para nasabah yang ingin menabung. Sistem Jemput bola merupakan cara dimana kita sebagai penyedia jasa/penjual produk mendatangi nasabah satu persatu untuk menabung. Dalam hal ini, karyawan di nilai positif oleh nasabah karena karyawan BMT Maslahah Capem Tegalsiwalan sangat baik dalam melayani nasabah.

Upaya karyawan dalam meningkatkan minat nasabah dalam menabung di lembaga keuangan syariah diharapkan pihak manajemen pengelolaan lembaga keuangan syariah dapat memahami sikap nasabah dalam memutuskan untuk memilih lembaga keuangan syariah. Nasabah akan berminat ke lembaga keuangan syariah jika ada produk dari lembaga tersebut yang menarik dan menguntungkan untuk nasabah, diantaranya karena faktor bagi hasil. Peningkatan kepercayaan nasabah di BMT Maslahah Capem Tegalsiwalan yang dibangun atas landasan nilai-nilai kemanusiaan dan keislaman. Dengan demikian, maka pelayanan BMT Maslahah Capem Tegalsiwalan dalam peningkatan ekonomi masyarakat juga ikut meningkat secara signifikan. Sistem ini mempermudah nasabah dan cenderung memilih BMT sebagai tempat untuk menabung. Dengan memberikan kepercayaan dari pihak BMT kepada nasabah, maka akan menjadi nilai tambah bagi pihak BMT yang menyediakan sistem pengelola dana dan dengan cara itu menjadi salah satu upaya karyawan dalam meningkatkan minat nasabah untuk menabung.

Melihat latar belakang diatas, maka peneliti tertarik untuk melakukan penelitian dengan judul "Strategi Karyawan Dalam Meningkatkan Minat Nasabah Menabung di BMT Maslahah Capem Tegalsiwalan”.

\section{KAJIAN PUSTAKA}

\section{BMT (Baitul Maal Wat Tamwil)}

BMT merupakan balai usaha mandiri terpadu berintikan baitul maal wattamwil yang diharapkan menjadi lembaga pendukung kegiatan ekonomi masyarakat kecil bawah dan kecil menengah dengan berdasarkan syariah. Baitul Maal Wattamwil adalah lembaga ekonomi atau keuangan syariah non perbankan yang sifatnya informal. Disebut informal karena lembaga ini didirikan oleh Kelompok Swadaya Masyarakat (KSM) yang berbeda dengan lembaga keuangan perbankan dan lembaga keuangan formal lainnya. ${ }^{4}$

${ }^{4}$ Ulfa Hasanah, Faktor-faktor motivasi yang dipertimbangkan nasabah dalam memilih BMT Pahlawan Tulungagung, (STAIN Tulungagung: Skripsi Tidak Diterbitkan,2010), 46. 
Peran umum BMT yang dilakukan adalah melakukan pembinaan dan pendanaan yang berdasarkan sistem syariah. Peran ini menegaskan arti penting prinsip-prinsip syariah dalam kehidupan ekonomi masyarakat. Sebagai lembaga keuangan syariah yang bersentuh langsung dengan kehidupan masyarakat kecil yang serba cukup ilmu pengetahuan dan materi, maka BMT mempunyai tugas penting dalam mengemban misi keislaman dalam segala aspek kehidupan masyarakat. Kegiatan BMT adalah pengembangan usaha-usaha produktif dan investasi dalam meningkatkan kualitas kegiatan ekonomi pengusaha, mendorong kegiatan menabung dan membantu pembiayaan kegiatan usaha ekonomi anggota dan masyarakat lingkungannya. BMT juga dapat berfungsi sosial dengan menggalang titipan dana sosial untuk kepentingan masyarakat, seperti dana zakat, infaq dan shadaqah dan mendistribusikannya dengan prinsip pemberdayaan masyarakat sesuai dengan peraturan dan amanahnya, kecil diantaranya dengan mendorong kegiatan menabung dan menunjang kegiatan ekonominya dengan sistem syariah. ${ }^{5}$

Baitul Maal Wattamwil sebenarnya merupakan dua kelembagaan yang menjadi satu, yaitu lembaga Baitul Maal dan Baitul Tamwil yang masingmasing keduanya memiliki prinsip dan produk yang berbeda meskipun memiliki hubungan yang erat antara keduanya dalam menciptakan suatu kondisi perekonomian yang merata dan dinamis.

Adapun Prinsip dan produk Baitul Maal Wattamwil adalah Baitul Maal yang sudah mengalami penyempitan arti di tengah masyarakat ini hanya memiliki prinsip sebagai penghimpun dan penyalur dana zakat, infaq, dan shadaqah, dalam arti bahwa Baitul Maal hanya bersifat "menunggu" kesadaran umat untuk menyalurkan dana zakat, infaq, dan shadaqah-nya saja yang kemudian setelah itu Baitul Maal menyalurkannya kepada mereka yang berhak untuk menerimanya.

Sedangkan Prinsip Baitul Tamwil adalah Baitul Tamwil tidak jauh berbeda dengan prinsip-prinsip yang digunakan Bank Islam. Ada 3 (tiga) prinsip yang dapat dilaksanakan oleh BMT (dalam fungsinya sebagai Baitul Tamwil), yaitu: prinsip bagi hasil, prinsip jual beli, dengan mark-up (keuntungan), dan prinsip nonprofit. ${ }^{6}$

a. Produk Inti Baitul Maal

1) Produk penghimpunan dana

Baitul Maal menerima dan mencari dana berupa zakat, infaq, dan shadaqah, meskipun selain sumber dana tersebut, Baitul Maal

${ }^{5}$ Ibid., 48.

${ }^{6}$ Jamal Lulail Yunus, “Manajemen Bank Syariah Mikro”, (Malang : UIN Press.2009), 33-36. 
juga menerima dana berupa sumbangan, hibah, ataupun wakaf serta dana-dana yang sifatnya sosial.

2) Produk penyaluran dana

Penyaluran dana yang bersumberkan dari dana Baitul Maal harus bersifat spesifik, terutama dana yang bersumber dari zakat, karena dana zakat ini sarana penyalurannya sudah ditetapkan secara tegas dalam al- Qur'an.

b. Produk Inti Baitul Tamwil

1) Produk penghimpunan dana

a) Al-Wadi'ah

b) Al-Mudharabah

c) Amanah

2) Produk penyaluran dana

a) Pembiayaan Mudharabah

b) Pembiayaan Musyarakah

c) Pembiayaan Murabahah

d) Pembiayaan Bai'Bitsaman Ajil

e) Pembiayaan Al-Qardhul Hasan

\section{Strategi dan Upaya Karyawan}

John A. Byrne mendefinisikan strategi adalah sebagai sebuah pola yang mendasar dari sasaran yang berjalan dan yang direncanakan, penyebaran sumber daya dan interaksi organisasi dengan pasar, pesaing, dan faktor-faktor lingkungan?

Ukuran keberhasilan dalam menerapkan strategi adalah mampu memberikan kepuasan kepada para pelanggan. Jadi, semakin banyak pelanggan yang menerima produk atau jasa yang ditawarkan, maka semakin puas dan strategi pun dianggap berhasil.

1. Pengertian Upaya

Upaya berarti usaha, akal, ikhtiar untuk mencapai suatu maksud, memecahkan persoalan dan mencari jalan keluar. ${ }^{8}$.

\section{Pengertian Karyawan}

Karyawan disebut juga dengan melayani, yakni perbuatan untuk menyediakan yang diperlukan orang lain karena seringkali untuk memenuhi kebutuhan tidak dapat dilakukan sendiri melainkan memerlukan bantuan berupa perbuatan orang lain.

3. Fungsi dan Tugas Karyawan

${ }^{7}$ Ali Hasan, Marketing Bank Syariah, (Bogor: Ghalia Indonesia, 2010), 29.

${ }^{8}$ Ahmad A.K. Muda, Kamus Lengkap Bahasa Indonesia (Reality Publisher, 2006), 555. 
Kasmir menyatakan bahwa karyawan mempunyai fungsi dan tugas sebagai resepsionis. Sebagai resepsionis, fungsi costumer service adalah menerima tamu yang datang ke bank, dengan ramah, sopan, simpatik, menarik, hangat dan menyenangkan dan membantu (helpful). ${ }^{9}$

4. Pelayanan Karyawan

Dalam KBBI disebutkan bahwa pengertian pelayanan adalah perihal atau cara melayani. ${ }^{10}$ Yakni perbuatan untuk menyediakan segala yang diperlukan orang lain atau proses pemenuhan kebutuhan melalui aktifitas orang lain. Salah satu unsur penting pelayanan yaitu perilaku yang sopan dan beradab yang dikenal dengan istilah Courtesy (adab sopan santun). Courtesy menyangkut cara penerimaan yang tulus dan ramah dalam melayani/menyambut tamu, tutur kata dan bicara yang ramah, tindakan yang dapat menyenangkan tamu dan memberikan fasilitas yang nyaman. Pelayanan yang baik harus segera dipenuhi sehingga keinginan nasabah dapat terpenuhi.

Adapun ciri-ciri pelayanan yang baik adalah :

a. Tersedia sarana dan prasarana yang baik

b. Tersedia karyawan yang baik

c. Bertanggung jawab kepada setiap nasabah sejak awal hingga selesai

d. Mampu melayani secara cepat dan tepat

e. Mampu berkomunikasi

f. Memberikan jaminan keberhasilan kerahasian setiap transaksi

g. Memiliki pengetahuan dan kemampuan yang baik

h. Berusaha memenuhi kebutuhan nasabah

i. Mampu memberikan kepercayaan kepada nasabah ${ }^{11}$

j. $\quad$ aktivitas yang lainnya. ${ }^{12}$

Minat dapat diartikan suatu keinginan yang timbul dari suatu perhatian seseorang terhadap barang, benda atau dapat juga dikatakan dorongan ingin melakukan kegiatan tertentu. Minat sama artinya dengan perhatian, antara minat dan perhatian pada umumnya dianggap sama/tidak ada perbedaan. Memang keduanya hampir sama dan dalam praktek selalu bergandengan satu sama lain. jika seseorang yang tertuju pada suatu obyek sebenarnya dimulai dengan adanya minat dalam hal tersebut. Minat ialah sikap jiwa orang seorang termasuk ketiga fungsi jiwanya (kognisi, konasi, emosi), yang tertuju pada suatu dan dalam hubungan itu unsur perasaan yang terkuat.

\footnotetext{
${ }^{9}$ Kasmir, Dasar-dasar Perbankan Ed. Revisi (Jakarta: Rajawali Pers, 2015), 92.

${ }^{10}$ Ahmad A.K. Muda, Kamus Lengkap Bahasa Indonesia (Reality Publisher, 2006), 555.

${ }^{11}$ Rambat Lupioyadi, Manajemen Pemasaran Jasa Teori dan Praktik (Jakarta: PT Salemba Empat, 2006), 65.

${ }^{12}$ Anton M. Moeliono Tata Bahasa Baku Bahasa Indonesia (Jakarta: Balai pustaka, 1999), 225.
} 
Perhatian ialah keaktifan jiwa yang diarahkan kepada sesuatu obyek tertentu. Di dalam gejala perhatian, ketiga fungsi tersebut juga ada, tetapi unsur pikiranlah yang terkuat pengaruhnya. Antara minat dan perhatian selalu berhubungan dengan praktek. Apa yang menarik minat dapat menyebabkan adanya perhatian dan apa yang menyebabkan adanya perhatian kita terhadap suatu tentu disertai dengan minat. ${ }^{13}$

Minat merupakan suatu kecenderungan untuk memberikan perhatian dan bertindak terhadap orang, aktifitas atau situasi yang menjadi objek dari minat tersebut dengan disertai perasaan senang. Dengan kata lain ada suatu usaha (untuk mendekati, mengetahui,menguasai dan berhubungan) dari subyek yang dilakukan dengan perasaan senang, ada daya tarik dari objek. ${ }^{14}$

Adapun definisi Tabungan adalah simpanan anggota kepada lembaga keuangan yang bersifat titipan dan dapat diambil sewaktu-waktu (setiap saat). Sedangkan pengertian simpanan adalah dana yang dipercayakan oleh anggota, calon anggota, koperasi lain dan anggotanya kepada koperasi dalam bentuk simpanan tabungan dan simpanan berjangka. ${ }^{15}$

a. Tabungan ada dua jenis :

1) Tabungan yang tidak dibenarkan secara syari'ah, yaitu tabungan yang berdasarkan perhitungan bunga.

2) Tabungan yang dibenarkan, yaitu tabungan yang berdasarkan prinsip mudharabah dan wadi'ah. ${ }^{16}$

"Menabung" diartikan menyimpan uang. Menabung sebagai sifat hemat dapat dijadikan sifat positif yang apabila dengan konsisten akan meningkatkan kualitas hidup yang lebih baik. ${ }^{17}$ Menabung adalah tindakan yang dianjurkan oleh islam, karena dengan menabung berarti seseorang muslim mempersiapkan diri untuk pelaksanaan perencanaan masa yang akan datang sekaligus untuk menghadapi hal-hal yang tidak diinginkan.

Dari pengertian tersebut tersirat bahwa orang yang menabung mempunyai hak untuk memperoleh kembali tabungannya dengan syarat tertentu. Dengan demikian, tabungan juga memberikan manfaat fungsional, prkatis serta untuk memenuhi kebutuhan dan keinginan nasabah. Menabung merupakan kegiatan aktivitas yang memerlukan adanya keinginan dalam diri seseorang.

Ada beberapa alat dalam tabungan, hal ini tergantung dari persyaratan masing-masing bank mau menggunakan sarana yang mereka inginkan. Alat

\footnotetext{
${ }^{13}$ Abu Ahmadi, Psikologi Umum, (Jakarta: PT RINEKA CIPTA, 2003), 151.

${ }^{14}$ Abdul Rahman Shaleh dan Muhbid Abdul Wahab, Psikologi Suatu Pengantar Dalam Prespektif Islam, (Jakarta: Prenada Media, 2004), 263.

${ }^{15}$ Ahmad Ifham Sholihin, Pedoman Umum Lembaga Keuangan Syari'ah, Jakarta : PT. Gramedia Pustaka Utama, 2010, 456.

${ }^{16}$ Ibid., 137.

${ }^{17}$ https://kbbi.web.id/nasabah.html, Di akses pada tanggal 20 februari 201914.15 WIB.
} 
ini dapat digunakan sendiri-sendiri atau secara bersamaan. Alat yang dimaksud antara lain adalah :
a. Buku tabungan
b. Slip penarikan

\section{METODE PENELITIAN}

Dalam sebuah penelitian kita mengenal jenis atau ragam penelitian yang diantaranya adalah penelitian kualitatif dan penelitian kuantitatif. Namun untuk memperoleh gambaran tentang upaya karyawan dalam meningkatkan minat nasabah menabung, maka peneliti menggunakan pendekatan penelitian kualitatif. Penelitian ini merupakan penelitian kualitatif dengan menggunakan pendekatan deskriptif, yaitu data yang dikumpulkan oleh penulis lebih dominan dalam bentuk kata-kata atau gambar daripada angka-angka. Hasil penelitian berisi kutipan-kutipan dari data untuk menggambarkan dan menyediakan bukti presentasi. Data tersebut meliputi transkip wawancara, catatan lapangan, foto dan rekamanrekaman resmi lainnya.

Dalam hal ini peneliti menggunakan penelitian studi kasus yaitu dengan meneliti langsung pada obyek yang akan diteliti. Disini yang akan diteliti adalah karyawan BMT Maslahah Capem Tegalsiwalan. Adapun fungsi dari pendekatan penelitian adalah untuk mengetahui tentang Strategi Karyawan Dalam Meningkatkan Minat Nasabah Menabung di BMT Maslahah Capem Tegalsiwalan.

Sumber data peneliti merupakan faktor penting yang menjadi pertimbangan yang menentukan metode pengumpulan data. Sumber data yang digunakan dalam penelitian ini adalah data primer dan data sekunder.

a. Data Primer

Data primer yang diperoleh peneliti dari informan yaitu :

1) Pimpinan BMT Maslahah Capem Tegalsiwalan

2) Karyawan BMT Maslahah Capem Tegalsiwalan

3) Nasabah BMT Maslahah Capem Tegalsiwalan

\section{b. Data Sekunder}

Data sekunder adalah data yang diperoleh dari sumber kedua atau sumber sekunder dari data yang kita butuhkan. ${ }^{18}$ Data sekunder merupakan data yang bukan diusahakan sendiri oleh peneliti, misalnya data yang

${ }^{18}$ Ibid., 122. 
diperoleh dari literatur-literatur kepustakaan seperti buku-buku, artikel, internet serta sumber lainnya.

Adapun prosedur pengumpulan data merupakan langkah yang paling utama dalam penelitian, karena tujuan dari penelitian untuk mendapatkan data. Tanpa mengetahui prosedur pengumpulan data, maka peneliti tidak akan mendapatkan data yang memenuhi standar data yang ditetapkan.

Agar dalam penelitian ini dapat diperoleh data-data yang relevan, peneliti menggunakan beberapa metode pengumpulan data yaitu:

a. Metode Observasi

b. Metode Wawancara

c. Metode Dokumentasi

Analisis data merupakan upaya mencari dan menata secara sistematis catatan hasil observasi, wawancara dan lainnya untuk meningkatkan pemahaman peneliti tentang kasus yang diteliti dan menyajikan sebagai temuan bagi orang lain. Sedangkan untuk meningkatkan pemahaman tersebut perlu dilanjutkan dengan berupaya mencari makna. ${ }^{19}$

Proses analisis data dimulai dengan menelaah seluruh data yang tersedia dari berbagai sumber yaitu dari wawancara, pengamatan yang sudah dituliskan dalam catatan lapangan, dokumen pribadi, dokumen resmi, gambar foto dan lainnya. Setelah data diperoleh dan sudah terkumpul, maka langkah selanjutnya adalah menyusun data tersebut dengan menggunakan analisis deskriptif, yaitu semua data yang terkumpul berupa kata-kata, gambar dengan pertimbangan bahwa penelitian ini berusaha menggambarkan dan menjelaskan data secara sistematis, ringkas dan sederhana. Yakni data yang terkait tentang bagaimana Strategi Karyawan Dalam Meningkatkan Minat Masabah Menabung di BMT Maslahah Capem Tegalsiwalan, sehingga lebih mudah dipahami oleh peneliti dan orang lain yang tertarik dengan hasil penelitian yang telah dilakukan.

Kemudian tahap terakhir dari analisis data ini adalah mengadakan pemeriksaan keabsahan data. Setelah tahap ini selesai, mulailah pada tahap pembahasan hasil penelitian.

Setelah berbagai data terkumpul, maka untuk menganilisisnya digunakan tekhnik analisis deskriptif, artinya peneliti berupaya menggambarkan kembali data-data yang telah terkumpul mengani bagaimana Strategi Karyawan Dalam Meningkatkan Minat Nasabah Menabung.tekhnik analisis deskriptif adalah cara menentukan dan menafsirkan data yang ada, misalnya tentang situasi yang dialami, suatu hubungan kegiatan, kecenderungan yang sedang mucul dan suatu proses yang sedang berlangsung.

\footnotetext{
${ }^{19}$ Noeng Muhajir, Metodologi Penelitian Kualitatif(Yogyakarta: Rake Sarasin, 1996), 104.
} 


\section{TEMUAN DAN PEMBAHASAN}

Baitul Maal wa Tamwil (BMT) Maslahah Capem Tegalsiwalan yang berlokasi di desa Sumber Bulu kecamatan Tegalsiwalan Kabupaten Probolinggo merupakan lembaga keuangan yang menerapkan sistem yang berpedoman pada syari'ah Islam. Dalam penerapannnya tidak menggunakan prinsip bunga (Riba) melainkan menggunakan prinsip bagi hasil (Nisbah) sehingga menjamin kehalalan pendapatannya.

1. Upaya Karyawan dalam Meningkatkan Minat Nasabah Menabung di BMT Maslahah Capem Tegalsiwalan

Adapun strategi pemasaran dalam produk tabungan yang dilakukan oleh karyawan BMT Maslahah Capem Tegalsiwalan adalah mengenali terlebih dahulu masyarakat yang akan menjadi target nasabah baru, kemudian melakukan penawaran sekaligus pengenalan produk yang ada di BMT.

BMT Maslahah Capem Tegalsiwalan dalam melakukan strategi pemasarannya yaitu dengan cara pendekatan kepada masyarakat setempat, baik untuk memahami karakter yang akan dijadikan target nasabah baru.

Pimpinan BMT Maslahah Capem Tegalsiwalan telah menegaskan bahwa setiap bertemu dengan nasabah, karyawan diharuskan untuk terus meningkatkan pelayanan dalam melayani nasabah dengan baik. Karyawan BMT memprioritaskan kepuasan nasabah melalui pelayanan yang optimal dan terbaik.

Karyawan BMT Maslahah Capem Tegalsiwalan ingin memberikan yang terbaik kepada nasabahnya. Nasabah pada intinya ingin diberikan pelayanan yang baik. Pelayanan yang baik harus segera dipenuhi sehingga keinginan nasabah dapat terpenuhi. Menurut hasil interview dengan beberapa karyawan BMT Maslahah Capem Tegalsiwalan antara lain :

a. Tersedia sarana dan prasarana yang baik

b. Tersedia karyawan yang baik

c. Bertanggung jawab kepada setiap nasabah sejak awal hingga selesai

d. Mampu melayani secara cepat dan tepat

e. Mampu Berkomunikasi

f. Memberikan jaminan keberhasilan kerahasian setiap transaksi

g. Memiliki pengetahuan dan kemampuan yang baik

h. Berusaha memenuhi kebutuhan nasabah

i. Mampu memberikan kepercayaan kepada nasabah

2. Faktor Pendukung Karyawan dalam Meningkatkan Minat Nasabah Menabung di BMT Maslahah Capem Tegalsiwalan 
BMT Maslahah Capem Tegalsiwalan meyediakan layanan jemput bola, dimana sistem jemput bola merupakan strategi karyawan untuk menjemput uang nasabah kerumah anggota atau ke pasar yang hendak menabung. Dengan adanya sistem jemput bola, karyawan tidak perlu repotrepot lagi untuk datang ke BMT Maslahah Capem Tegalsiwalan.

Hal ini dibuktikan dengan hasil wawancara yang telah diperoleh dengan Bapak Imam Hidayat tentang strategi pemasaran produk tabungan yakni sebagai berikut :

Kami meyediakan layanan jemput bola kerumah nasabah atau ke pasar untuk melayani penyetoran maupun penarikan. Kecuali untuk penarikan tabungan maka nasabah harus datang ke BMT dengan membawa KTP untuk mecocokkan data yang ada dikomputer.Selain itu, BMT juga menyediakan Mobile Mini Printer (Alat untuk menabung), yang digunakan oleh AOSP untuk mendata nasabah yang hendak menabung. Dengan tersedianya mobile mini printer nasabah merasa lebih aman dan tidak khawatir lagi jika uang yang ingin di tabung benar-benar sudah terdata. ${ }^{20}$

Adapun alasan BMT Maslahah Capem Tegalsiwalan memilih strategi pemasaran tersebut karena untuk mencapai suatu ke efisiensian lembaga keuangan. Sebagian besar dari mereka tidak punya banyak waktu datang ke kantor untuk menabung. Jadi dengan strategi tersebut dapat menarik minat nasabah yang ingin menabung. Mobile Mini Printer (Alat untuk menabung), yang digunakan oleh AOSP untuk mendata nasabah yang hendak menabung membuat nasabah merasa lebih aman dan tidak khawatir lagi jika uang yang ingin di tabung benar-benar sudah terdata. Berdasarkan pengalaman sebelumnya, sebelum adanya mobile mini printer nasabah tidak terlalu yakin dan masih ada rasa khawatir jika uang yang di tabung tidak benarbenar terdata. Jadi, mobile mini printer juga termasuk fasilitas dari bagian tabungan untuk meyakinkan nasabah bahwa uang yang hendak di tabung sudah terdata.

Menurut pemaparan Ibu Nursia salah satu nasabah BMT Maslahah Capem Tegalsiwalan yakni sebagai berikut :

Keberadaan BMT Maslahah Capem Tegalsiwalan bermanfaat bagi saya pribadi karna pelayanan yang diberikan oleh karyawan BMT sangat memuaskan. Sistem yang mereka gunakan sangat mendukung saya yang seorang pedagang. Ketika saya ingin menabung tidak perlu

${ }^{20}$ Lihat lampiran 11/1-W/F-2/16-VII/2019 
repot-repot dating langsung ke BMT, karna setiap hari karyawan sudah mejemput uang tabungan saya. ${ }^{21}$

Dengan adanya strategi pemasaran yang dilakukan BMT Maslahah Capem Tegalsiwalan yaitu dengan memprioritaskan pelayanan yang terbaik terhadap nasabah seperti layanan sistem jemput bola, sehingga terciptalah pencitraan yang baik bagi lembaga. Kemudian dengan adanya citra yang baik maka nasabah dengan sendirinya akan membawa minat bagi masyarakat lainnya. Citra yang baik akan menghilangkan pandangan negatif terhadap BMT.

BMT Maslahah Capem Tegalsiwalan memiliki beberapa produk. Hal ini juga dibuktikan dengan hasil wawancara yang telah diperoleh dengan Bapak Imam Hidayat selaku Pimpinan BMT, yakni sebagai berikut :

\section{Tabungan}

a. Tabungan pendidikan

Tabungan ini digunakan untuk pembayaran pendidikan. Tabungan ini dapat diambil ketika ingin membayar pendidikan sesuai dengan kesepakatan bersama.

b. Tabungan Idul Fitri

Tabungan ini untuk memenuhi kebutuhan saat menjelang hari raya Idul Fitri atau sebulan sebelum hari raya dan tabungan ini hanya bisa diambil satu kali dalam setahun.

c. Tabungan Qurban

Tabungan ini sebagai sarana untuk memantapkan niat untuk melaksanakan ibadah qurban pada hari raya Idul Adha. Pengambilan hanya dapat dilakukan ketika menjelang hari raya Idul Adha.

d. Deposito syari'ah

Simpanan ini bisa ditarik berdasarkan jangka waktu yang telah disepakati yaitu tiga bulan, enam bulan, Sembilan bulan, dan dua belas bulan (satu tahun).

e. Tabungan ziarah

Tabungan ini digunakan untuk keperluan ziarah. Pengambilannya dapat dilakukan sesuai dengan kesepakatan bersama.

f. Tabungan haji dan umroh

Tabungan ini hanya bisa diambil apabila ingin menunaikan ibadah haji atau melaksanakan ibadah umroh.

\section{Pembiayaan}

BMT Maslahah Capem Tegalsiwalan tidak hanya memiliki produk tabungan dan deposito saja, melainkan juga mempunyai produk

${ }^{21}$ Lihat lampiran 11/2-W/F-2/21-VII/2019 
pembiayaan. Adapun beberapa jenis atau macam pembiayaan yang ditawarkan pada nasabah adalah sebagai berikut:

a) Mudharabah (Bagi Hasil)

Pembiayaan modal kerja sepenuhnya ditanggung oleh BMT sedangkan nasabah yang harus menyediakan usaha dan manejemennya. Hasil keuntungan akan dibagi sesuai dengan kesepakatan antara kedua belah pihak berdasarkan ketentuan hasil yang diperoleh.

b) Murobahah (Modal Kerja)

Pembiayaan jual beli yang pembayarannya dilakukan pada saat jatuh tempo dan satu kali lunas beserta mark-up (laba) sesuai dengan kesepakatan bersama.

c) Musyarokah (Penyertaan)

Pembiayaan berupa sebagian modal yang diberikan kepada anggota dari modal keseluruhan. Masing-masing dari pihak yang bekerja memiliki hak untuk turut serta mewakili atau menggugurkan haknya dalam manejemen usaha tersebut. Keuntungan dari usaha ini akan dibagi menurut proporsi penyertaan modal sesuai dengan kesepakatan.

d) Qordul hasan

Qordul hasan adalah pembiayaan dari harta yang dikhususkan untuk dikembalikan sesuai dengan jumlah pembiayaan tanpa memberikan bagi hasil. Diperuntukkan bagi kaum dhuafa (mereka yang kurang mampu). ${ }^{22}$

Adapun produk yang paling diminati oleh masyarakat adalah produk Tabungan Mudharabah karna sistemnya mudah dan tidak memberatkan nasabah bahkan bisa diambil sewaktu-waktu ketika dibutuhkan. Selain itu, nasabah juga bebas dari administrasi bulanan. Sementara itu, bagi hasil dihitung atas dasar rata-rata saldo bulanan dan nisbahnya tergantung dari hasil pendapatan koperasi di BMT setiap bulan, dan banyaknya nasabah. Demikian pula akad yang digunakan BMT Maslahah Capem Tegalsiwalan adalah akad mudharabah dan wadiah.

Sistem yang digunakan di BMT Maslahah Capem Tegalsiwalan terkait bagi hasil untuk tabungan mudharabah ialah sistem pemberian hadiah kepada semua anggota yang mempunyai tabungan dan saldo minimal Rp 1.000 .000 dengan presentase $0.12 \%$ dari saldo akhir. Misalanya sebagai berikut:

\begin{tabular}{l|l|l|l} 
Nama & Saldo tabungan di akhir & Persentase hadiah & Nominal
\end{tabular}

${ }^{22}$ Lihat lampiran 11/3-W/F-2/16-VII/2019 


\begin{tabular}{|c|c|c|c|}
\hline anggota & bulan & & hadiah \\
\hline A & 5.000 .000 & 0,12 & 6.000 \\
\hline B & 2.000 .000 & 0,12 & 2.400 \\
\hline C & 1.000 .000 & 0,12 & 1.200 \\
\hline
\end{tabular}

Pada tabel diatas dapat kita ketahui bahwasanya setiap jumlah tabungan nasabah yang telah mencapai minimal Rp 1.000.000 maka akan mendapatkan (nisbah) bagi hasil senilai $0,12 \%$, misalnya anggota A yang mempunyai saldo tabungan Rp 5.000.000 maka akan mendapat bagi hasil dari BMT Maslahah Capem Tegalsiwalan sebesar Rp 6.000 dan anggota $\mathrm{C}$ yang mempunyai jumlah saldo tabungan $\mathrm{Rp}$ 1.000.000 maka akan mendapat bagi hasil sebesar Rp 1.200 begitupun Seterusnya besar nilai bagi hasil yang diterima oleh nasabah tergantung dari jumlah tabungan nasabah yyang ada di BMT.

Adapun alasan nasabah lebih berminat pada tabungan mudharabah daripada produk tabungan yang lain (tabungan pendidikan, tabungan fitri, tabungan qurban, tabungan ziaroh, dll) dikarenakan bisa diambil sewaktu-waktu serta nasabah akan mendapat bagi hasil dari BMT Maslahah Capem Tegalswilan dengan catatan minimal tabunganya mencapai satu juta rupiah, sehingga tidak sedikit dari setiap masyarakat lebih berminat pada tabungan mudharabah tersebut daripada berbagai aneka ragam produk tabungan yang disediakan BMT Maslahah Capem Tegalsiwalan.

\section{Faktor Penghambat Karyawan dalam Meningkatkan Minat Nasabah Menabung di BMT Maslahah Capem Tegalsiwalan}

Kendala merupakan sebuah halangan atau rintangan yang harus dihadapi oleh karyawan BMT Maslahah Capem Tegalsiwalan. Kendala itu sendiri, bisa menjadi masalah penting yang harus dihadapi oleh setiap lembaga keuangan termasuk BMT Maslahah Capem Tegalsiwalan. Kendala merupakan hal penting untuk segera diatasi agar tidak berpengaruh pada usaha yang sedang dijalankan. Akan tetapi, saat di wawancarai mengenai kendala yang dihadapi oleh BMT Maslahah Capem Tegalsiwalan, Bapak Abdur Rohim mengatakan bahwa :

Sulitnya pemasaran dalam mempromosikan produk tabungan yang ada di BMT kepada masyarakat, seperti kurangnya pengetahuan masyarakat akan adanya BMT, serta keyakinan masyarakat untuk menitipkan uangnya di BMT, karena sebagian masyarakat masih beranggapan BMT mudah mengalami kerugian. Selain itu, tidak tersedianya kartu ATM, dan terbatasnya brosur di BMT Maslahah Capem Tegalsiwalan. Sehingga ketika ada nasabah yang datang ke 
kantor untuk melakukan penyetoran atau pembukaan rekening baru, terkadang juga meminta brosur, maka teller terkadang harus meminta maaf kepada anggota karena terbatasnya brosur yang tersedia. ${ }^{23}$

Kendalanya yaitu sulitnya pemasaran dalam mempromosikan produk tabungan di BMT Maslahah Capem Tegalsiwalan, untuk itu dibutuhkan juga kesabaran serta selalu meyakinkan masyarakat (nasabah) agar tetap percaya terhadap kinerja karyawan BMT Maslahah Capem Tegalsiwalan sehingga lembaga tersebut bisa menyempurnakan adanya kendala yang terjadi. Adapun untuk mengatasi kendala tersebut yaitu dengan cara menjelaskan keunggulan produk yang ada di BMT Maslahah Capem Tegalsiwalan kepada masyarakat denga tujuan agar masyarakat percaya dengan lembaga tersebut. Selain itu, kendala yang lain adalah terbatasnya brosur dan tidak tersedia kartu ATM. Seperti yang peneliti dapatkan dalam proses wawancara dengan Bapak Baitul Ulum, ia mengatakan bahwa :

Kita perlu menjelaskan secara menyeluruh mengenai produk kita, selain itu kita harus membuat masyarakat percaya dengan BMT Maslahah Capem Tegalsiwalan. Seperti tadi, memprioritaskan kepuasan nasabah. Karena nasabah yang puas akan menjadi loyal dan dari kepuasan nasabah nantinya akan tercipta promosi dari mulut ke mulut, dari satu nasabah ke nasabah ke yang lain sehingga ini akan meningkatkan citra baik BMT Maslahah Capem Tegalsiwalan di masyarakat, dimana citra yang baik ini akan menghilangkan pandangan negatif masyarakat terhadap BMT. ${ }^{24}$

Untuk mengatasi kendala yang dihadapi maka pihak BMT perlu mejelaskan mengenai produk yang ada di BMT kepada masyarakat secara perinci, sehingga terciptalah sebuah kepercayaan dari masyarakat kepada pihak BMT Maslahah Capem Tegalsiwalan.

\section{ANALISIS DATA}

\section{Upaya Karyawan Dalam Meningkatkan Minat Nasabah Menabung di BMT Maslahah Capem Tegalsiwalan}

Upaya karyawan dalam meningkatkan minat nasabah menabung di BMT Maslahah Capem Tegalsiwalan yaitu, Pimpinan BMT telah menegaskan bahwa setiap bertemu dengan nasabah, karyawan diharuskan

\footnotetext{
${ }^{23}$ Lihat lampiran 12/1-W/F-3/16-VII/2019

${ }^{24}$ Lihat lampiran 12/2-W/F-3/16-VII/2019
} 
untuk terus meningkatkan pelayanan dalam melayani nasabah dengan baik. Di harapkan pihak manajemen pengelolaan lembaga keuangan syariah dapat memahami sikap nasabah dalam memutuskan untuk memilih lembaga keuangan syariah. Peningkatan kepercayaan nasabah di BMT Maslahah Capem Tegalsiwalan dibangun atas landasan nilai-nilai kemanusiaan dan keislaman. Dengan demikian, pelayanan BMT Maslahah Capem Tegalsiwalan dalam peningkatan ekonomi masyarakat juga ikut meningkat secara signifikan. Sistem ini mempermudah nasabah dan cenderung memilih BMT sebagai tempat untuk dijadikan media penyimpanan uang.

Pertama, Kenali masyarakat/nasabah. Nasabah menjadi hal terpenting dalam keberlangsungan usaha yang di jalankan. Untuk mengenal apa yang dia mau, apa yang dia butuhkan, dan bagaimana dia bisa mengenal kita. Mengenali masyarakat terlebih dahulu menjadi hal wajib yang harus dilakukan agar bisa menciptakan komunikasi yang baik antara karyawan dengan nasabah. Untuk itu mengenali nasabah juga termasuk strategi yang harus di ketahui.

Kedua, yaitu pelayanan. Pelayanan sebagai tindakan atau perbuatan seseorang untuk memberikan kepuasan kepada pelanggan atau nasabah. Tindakan tersebut dapat dilakukan melalui cara melayani pelanggan langsung. Artinya karyawan langsung berhadapan dengan pelanggan atau menetapkan sesuatu dimana pelanggan/nasabah akan bertemu. Tindakan yang dilakukan guna memenuhi kebutuhan pelanggan/nasabah akan suatu produk atau jasa yang mereka butuhkan. Pelayanan merupakan perbuatan untuk menyediakan segala yang diperlukan orang lain atau proses pemenuhan kebutuhan melalui aktifitas orang lain. Salah satu unsur penting pelayanan yaitu perilaku yang sopan dan beradab yang dikenal dengan istilah Courtesy (adab sopan santun). Courtesy menyangkut cara penerimaan yang tulus dan ramah dalam melayani/menyambut tamu, tutur kata dan bicara yang ramah, tindakan yang dapat menyenangkan tamu dan memberikan fasilitas yang nyaman.

Karyawan BMT Maslahah Capem Tegalsiwalan ingin memberikan yang terbaik kepada nasabahnya. Nasabah pada intinya ingin diberikan pelayanan yang baik. Pelayanan yang baik harus segera dipenuhi sehingga keinginan nasabah dapat terpenuhi. Menurut hasil interview dengan beberapa karyawan BMT Maslahah Capem Tegalsiwalan terkait dengan pelayanan yang harus dierikan oleh karyawan kepada nasabah yaitu, Tersedia sarana dan prasarana yang baik, Tersedia karyawan yang baik, Bertanggung jawab kepada setiap nasabah sejak awal hingga selesai, Mampu melayani secara cepat dan tepat, Mampu berkomunikasi, Memberikan jaminan keberhasilan kerahasiaan setiap transaksi, Memiliki 
pengetahuan dan kemampuan yang baik, Berusaha memenuhi kebutuhan nasabah dan Mampu memberikan kepercayaan kepada nasabah.

Kepuasan nasabah adalah tingkat perasaan seseorang setelah membandingkan kinerja atau hasil yang ia rasakan dibandingkan dengan harapannya. kepuasan nasabah hanya dapat tercapai dengan memberikan pelayanan yang nyaman dan baik kepada para calon nasabah. Pelayanan yang baik sering dinilai oleh para nasabah secara langsung, untuk itu di perlukan usaha untuk meningkatkan kualitas sistem pelayanan yang di berikan agar dapat memenuhi keinginan dan meningkatkan kepuasan para nasabah. Jadi kualitas pelayanan merupakan hal penting yang harus di perhatikan oleh para karyawan di BMT Maslahah Capem Tegalsiwalan agar dapat tercapai kepuasan nasabah. Kualitas pelayanan memberikan suatu dorongan kepada nasabah untuk menjalin hubungan yang kuat dengan para karyawan dan kepuasan tersebut dapat menciptakan kesetiaan / loyalitas bagi para nasabah itu sendiri.

Dari hasil pemaparan diatas terbukti bahwasanya kinerja para karyawan BMT Maslahah Capem Tegalsiwalan sesuai dengan latar belakang mereka sebagai alumni Pondok Pesantren Sidogiri dan tetap berpanduan pada Visi-Misi berdirinya BMT, sehingga para nasabah merasa puas akan kinerja yang diberikan para karyawan. Dari kepuasan para nasabah akan menambah kepercayaan diri bagi BMT Maslahah Capem tegalsiwalan untuk tetap mempertahankan kualitas dan kuantitasnya dan meningkatkan minat nasabah baru untuk menabung.

\section{Faktor-Faktor Pendukung Upaya Karyawan Dalam Meningkatkan} Minat Nasabah Menabung di BMT Maslahah Capem Tegalsiwalan

Akhirnya setelah kami melakukan observasi selama beberapa waktu tertentu di BMT Maslahah Capem Tegalsiwalan, maka kami dapat menemukan serta dapat mendeskripsikan hasil dari penelitian diantaranya adalah sebagai berikut :

BMT Maslahah Capem Tegalsiwalan menyediakan layanan sistem jemput bola kerumah anggota atau ke pasar untuk melayani penyetoran maupun penarikan. Sistem jemput bola merupakan fasilitas dari bagian tabungan untuk mempermudah nasabah, sehingga bisa tertarik untuk menabung di BMT Maslahah Capem Tegalsiwalan. Dari ibu rumah tangga, pengusaha lalu ke pedagang-pedagang di pasar, nantinya pasti akan disebarkan dari satu orang ke orang lainnya.

Tersedianya Mobile Mini Printer (Alat untuk menabung), yang digunakan oleh AOSP untuk mendata nasabah yang hendak menabung. Dengan tersedianya mobile mini printer nasabah merasa lebih aman dan tidak khawatir lagi jika uang yang ingin di tabung benar-benar sudah 
terdata. Berdasarkan pengalaman sebelumnya, sebelum adanya mobile mini printer nasabah tidak terlalu yakin dan masih ada rasa khawatir jika uang yang di tabung tidak benar-benar terdata. Jadi, mobile mini printer juga termasuk fasilitas dari bagian tabungan untuk meyakinkan nasabah bahwa uang yang hendak di tabung sudah terdata.

Selanjutnya yaitu dengan adanya sistem bagi hasil (Nisbah) di BMT Maslahah Capem Maslahah Tegalsiwalan merupakan salah satu alasan masyarakat berminat untuk menabung, karna apabila dibandingkan dengan Lembaga Keuangan Konvensional seperti Bank yang tidak memberikan bagi hasil kepada nasabahnya, tetapi nasabah malah harus membayar riba (bunga).

3. Faktor-Faktor Penghambat Upaya Karyawan Dalam Meningkatkan Minat Nasabah Menabung di BMT Maslahah Capem Tegalsiwalan

Untuk hambatan ada dua yakni hambatan dari BMT sendiri dan hambatan dari masyarakat. Untuk hambatan dari BMT yaitu terbatasnya sarana pemasaran dan pelayanan di kantor BMT Maslahah Capem Tegalsiwalan, misalnya dalam penyebaran brosur, brosur yang tersedia di Kantor BMT sedikit sehingga ketika hendak melakukan pemasaran, karyawan harus ke kantor pusat terlebih dahulu untuk mengambil brosur dan terkadang stok brosur dikantor pusat pun juga terbatas. Jika ada anggota ada yang datang ke kantor untuk melakukan penyetoran atau pembukaan rekening baru dan nasabah tersebut meminta brosur, maka teller BMT Maslahah Capem Tegalsiwalan terkadang harus meminta maaf kepada anggota karena terbatasnya brosur yang tersedia dan memberikannya kepada anggota ketika sudah ada tambahan brosur dari kantor pusat. Seperti yang diungkapkan oleh Bapak Imam Hidayat Selaku Pimpinan BMT Maslahah Capem Tegalsiwalan.

Selain itu, karna tidak tersedianya kartu ATM di BMT Maslahah Capem Tegalsiwalan. Sehingga para nasabah masih berfikir lagi untuk menyimpan uangnya di BMT. Apabila dibandingkan dengan layanan Bank Konvensional yang sudah menyediakan kartu ATM dan juga bisa memudahkan para nasabah untuk mengambil uang apabila dibutuhkan, maka hal itu yang menjadi penghambat para nasabah untuk bergabung di BMT Maslahah Capem Tegalsiwalan.

Selain brosur, hambatan lainnya adalah dari masyarakat, yaitu banyaknya masyarakat yang tidak mudah percaya dengan BMT, karena masih melekat citra negatif dalam masyarakat, mereka beranggapan BMT tidak seaman bank dalam mengelola uang.

Selain brosur, hambatan lainnya adalah dari masyarakat, yaitu Sulitnya pemasaran dalam mempromosikan produk tabungan yang ada di 
BMT kepada masyarakat, seperti kurangnya pengetahuan masyarakat akan adanya BMT, serta keyakinan masyarakat untuk menitipkan uangnya di BMT, karena sebagian masyarakat masih beranggapan BMT mudah mengalami kerugian. Masyarakat yang tidak mudah percaya kepada lembaga BMT, karena masih melekat citra negatif dalam masyarakat, mereka beranggapan menabung di BMT tidak seaman di Bank dalam menyimpan ataupun mengelola uang.

\section{KESIMPULAN}

Berdasarkan penelitian yang telah kami lakukan serta hasil yang diperoleh seperti yang telah dideskripsikan pada pembahasan sebelumnya, maka dapat ditarik kesimpulan bahwa :

1. Upaya Karyawan Dalam Meningkatkan Minat Nasabah Menabung di BMT Maslahah Capem Tegalsiwalan yaitu, Pimpinan BMT telah menegaskan bahwa setiap bertemu dengan nasabah, karyawan diharuskan untuk terus meningkatkan pelayanan dalam melayani nasabah dengan baik. Sehingga nasabah merasa puas dengan pelayanan yang diberikan oleh karyawan. Selain itu, juga bisa meningkatkan minat nasabah untuk menabung di BMT Maslahah Capem Tegalsiwalan.

2. Faktor pendukung Upaya Karyawan Dalam Meningkatkan Minat Nasabah Menabung di BMT Maslahah Capem Tegalsiwalan adalah sistem bagi hasil, dan mobile mini printer yang menjadi landasan utama dalam kegiatan yang dilakukan di BMT Maslahah Capem Tegalsiwalan. Selain itu, karyawan mengaplikasikan "sistem jemput bola" yaitu dengan mendatangi para nasabah untuk menabung. Dalam hal ini karyawan dinilai positif oleh masyarakat bahwa karyawan BMT Maslahah Capem Tegalsiwalan, bahwa karyawan sangat menekuni dalam melayani nasabah.

3. Faktor penghambat Upaya Karyawan Dalam Meningkatkan Minat Nasabah Menabung di BMT Maslahah Capem Tegalsiwalan adalah sulitnya pemasaran produk tabungan kepada masyrakat, tidak tersedianya kartu ATM dan terbatasnya brosur yang ada di BMT Maslahah Capem Tegalsiwalan. 


\section{DAFTAR PUSTAKA}

Ahmadi, Abu. 2003. "Psikologi Umum.” Jakarta: PT RINEKA CIPTA.

Antonio, Muhammad Syafi'i. 2001.“Bank Syariah dari Teori ke Praktek.” Jakarta : Gema Insani

Hasan, Ali. 2010. “Marketing Bank Syariah.” Bogor: Ghalia Indonesia

Hasanah, Ulfa. 2010. "Faktor-faktor motivasi yang dipertimbangkan nasabah dalam memilih BMT Pahlawan Tulungagung”. STAIN Tulungagung: Skripsi Tidak Diterbitkan

Kasmir. 2015. “Dasar-dasar Perbankan Ed. Revisi”. Jakarta: Rajawali Pers

Lubis, Suhrawardi K. 2000. “Hukum Ekonomi Islam.” Jakarta: Sinar Grafika

Lupioyadi, Rambat. 2006. "Manajemen Pemasaran Jasa Teori dan Praktik". Jakarta: PT Salemba Empat

Muda, Ahmad A.K. 2006. “Kamus Lengkap Bahasa Indonesia.” Reality Publisher.

Muhajir, Noeng. 1996. “Metodologi Penelitian Kualitatif”. Yogyakarta: Rake Sarasin.

Moeliono, Anton M. 1999. “Tata Bahasa Baku Bahasa Indonesia”. Jakarta: Balai pustaka

Sholihin, Ahmad Ifham. 2010. “Buku Pintar Ekonomi Syariah.” Jakarta: PT Gramedia Pustaka Utama Kompas Gramedia Building

Ahmad Ifham. 2010. "Pedoman Umum Lembaga Keuangan Syari'ah." Jakarta : PT. Gramedia Pustaka Utama.

Wahab, Abdul Rahman Shaleh dan Muhbid Abdul. 2004. "Psikologi Suatu Pengantar Dalam Prespektif Islam.” Jakarta: Prenada Media.

Yunus, Jamal Lulail. 2009. “Manajemen Bank Syariah Mikro”. Malang : UIN Press. 